М.В. Сургай ${ }^{1}$, Г.С. Залевський ${ }^{1}$, С.А. Горелишев ${ }^{2}$, О.І. Угринович ${ }^{3}$, В.В. Джус ${ }^{1}$

${ }^{1}$ Харківський національний університет Повітряних Сил ім. I. Кожедуба, Харків

${ }^{2}$ Начіональна академія Національної гвардї України, Харків

${ }^{3}$ Національний університет оборони України ім. I. Черняховського, Київ

\title{
ВИБІР ПОЛОСИ ЧАСТОТ ЗОНДУВАЛЬНОГО СИГНАЛУ, ВІДПОВІДНОЇ МАКСИМАЛЬНОМУ РІВНЮ ВТОРИННОГО ВИПРОМІНЮВАННЯ ОБ'ЄКТІВ ЗАДАНИХ ТИПІВ
}

\begin{abstract}
Розглядаються питання узгодження полоси частот зондувального сигналу з різними повітряними об'єктами. Пропонується метод вибору раџіональної полоси частот зондувального сигналу для забезпечення максимального рівня вторинного випромінювання повітряних об'єктів заданих типів. Метод засновано на застосуванні електродинамічних математичних моделей вторинного випромінювання радіолокаційних об’єктів та оцінюванні усередненої за можливими ракурсами енергії відбитого сигналу, як функиії середньої частоти і иирини спектру зондувального сигналу. Наводяться і аналізуються результати розрахунку енергій відбитих сигналів для трьох різних типів снарядів артилерії у L та S діапазонах частот. Надано пропозиції щзодо вибору полоси частот для зондування різних типів снарядів.
\end{abstract}

Ключові слова: енергія відбитого сигналу, математичне моделювання вторинного випромінювання, радіолокаційна станція контрбатарейної боротьби, радіолокаційний об'єкт, полоса частот.

\section{Вступ}

Постановка проблеми. Сучасний етап розвитку радіолокаційного озброєння характеризується постійною появою нових об'єктів локації, які відрізняються різноманітністю властивостей, які впливають на їх вторинне випромінювання. Розробники радіолокаторів прагнуть забезпечити максимальний рівень інтенсивності відбитих сигналів (їх ефективної поверхні розсіювання, ЕПР). Одним із шляхів підвищення ЕПР $є$ раціональний вибір параметрів частотного спектру зондувального сигналу, при якому спостерігаються максимальні значення ЕПР. Враховуючи залежність рівня вторинного випромінювання від різноманіття конструкцій повітряних об'єктів, їх електричних розмірів і ракурсу, вирішення даної задачі є достатньо складним питанням. Разом із цим у випадку радіолокаційних станцій (РЛС) контрбатарейної боротьби (КББ) форма і електричні розміри об'єктів локації (снарядів різних типів) відрізняється не так істотно, і поставлена задача - вибору раціональної полоси частот спектру зондувального сигналу може бути вирішеною.

Вибір частотного діапазону РЛС залежить від об'єктів радіолокації та функцій, що вона виконує. У роботі [1] на результатах математичного моделювання характеристик вторинного випромінювання снарядів різних типів показано певні переваги застосування у РЛС КББ зондувального сигналу із спектром, відповідним верхній частині дециметрового діапазону частот (L, S діапазони). На практиці $\epsilon$ важливим більш детальне з'ясування раціональної полоси частот для зондування снарядів артилерії і систем залпового вогню.

При виборі полоси частот РЛС необхідно враховувати специфіку виконуваних нею функцій, об’єкти локації, дальність дії, точність вимірювання координат (якість супроводження), можливість вітчизняних підприємств щодо розробки і виробництва пристроїв генерування, випромінювання, прийому i обробки прийнятих сигналів. До сучасних радіолокаторів пред'являються жорсткі вимоги щодо мобільності, що у свою чергу визначає обмеження на їх габарити і вагу. Наведені фактори визначають вимоги до полоси робочих частот зондувального сигналу. Роботу присвячено розробці методу, який надасть можливість обирати полосу частот сигналів, у якій забезпечується максимум вторинного випромінювання визначених типів повітряних об'єктів у межах дециметрового діапазону частот.

Аналіз останніх досліджень та публікацій. Питанням узгодження частотного спектру зондувального сигналу із різними об'єктами локації (“узгоджене підсвічування”) присвячено цілий ряд робіт, зокрема [2-5]. Результати цих робіт як правило отримувались для спрощеного аналізу конструкції об'єктів локації, які належать до одного конкретного типу. Відомі результати можуть бути доповненими при більш детальному з'ясуванні характеристик вторинного випромінювання заданих типів об'єктів, що відрізняються за конструкцією і електричними розмірами [1; 6-15]. Визначене питання початково може бути вирішеним для радіолокаційного зонду- 
вання снарядів різних артилерійських (ракетних) систем, різноманіття яких не таке широке, як для РЛС протиповітряної оборони. Далі метод може бути розвинутим на більш складні повітряні цілі.

У роботах $[1 ; 13-14 ; 16-22]$ досліджуються характеристики вторинного випромінювання снарядів різних типів у різних діапазонах хвиль. Разом з цим задача визначення раціональної полоси частот зондувального сигналу не вирішується.

У роботах [1; 6-15] описано методи математичного моделювання різних повітряних об'єктів складної форми. Вони можуть застосовуватись для детального вивчення характеристик вторинного випромінювання моделей реальних об'єктів. У випадку снарядів, як металевих розсіювачів резонансних розмірів у дециметровому діапазоні довжин хвиль доцільно використовувати метод, заснований на розв'язанні інтегрального рівняння магнітного поля [1; 12-14].

У зв'язку з наведеним вище метою статті $є$ розробка методу визначення раціональної полоси частот зондувального сигналу для забезпечення максимуму інтенсивності вторинного випромінювання об’єктів локації декількох встановлених типів на основі використання математичного моделювання їх характеристик вторинного випромінювання. Ефективність запропонованого методу показується на прикладі снарядів трьох різних типів стосовно до РЛС КББ.

\section{Виклад основного матеріалу}

\section{1. Метод вибору полоси частот спектру зондувального сигналу, відповідної максимальній енергії відбиття від різних радіолокаційних об'єктів}

У роботі проведено розробку методу вибору полоси частот зондувального сигналу, яка відповідає максимуму вторинного випромінювання заданого числа радіолокаційних об'єктів. У якості критерію вибору полоси частот спектру зондувального сигналу будемо застосовувати максимальну середню енергію відбитих шуканими об'єктами сигналів, яка залежить від середньої частоти $f_{0}$ і ширини спектру зондувального сигналу $\Delta f=f_{2}-f_{1}$ :

$$
E_{c}\left(f_{0}, \Delta f\right)=\frac{1}{K} \sum_{k=1}^{K} E_{c k}\left(f_{0}, \Delta f\right),
$$

де $K$ - кількість шуканих об'єктів.

Середня енергія сигналу, відбитого $k$-м об'єктом $E_{c k}$, розраховується за наступною формулою:

$$
E_{c k}\left(f_{0}, \Delta f\right)=\frac{1}{N} \sum_{n=1}^{N} E\left(f_{0}, \Delta f, \varepsilon_{n}, \beta_{n}\right)
$$

де $N$ - кількість заданих ракурсів $k$-го радіолокаційного об’єкту. У випадку моностатичної РЛС, фіксований $n$-й ракурс характеризується кутом місця $\varepsilon_{n}$ i азимутом $\beta_{n}$ опромінення. У бістатичному випадку необхідно враховувати кути місця і азимути опромінювання і прийому.

Енергія сигналу, відбитого $k$-м об'єктом при фіксованих кутах $\varepsilon_{n}, \beta_{n}$, може бути розрахованою за допомогою наступного виразу [8]:

$$
E\left(f_{0}, \Delta f, \varepsilon_{n}, \beta_{n}\right)=\int_{f_{1}}^{f_{2}}\left|G_{n p}\left(f, \varepsilon_{n}, \beta_{n}\right)\right|^{2} d f,
$$

де $G_{n p}\left(f, \varepsilon_{n}, \beta_{n}\right)$ - комплексний частотний спектр сигналу, відбитого $k$-м об'єктом при фіксованому ракурсі $\left(\varepsilon_{n}, \beta_{n}\right)$ та при його опроміненні сигналом iз рівномірним амплітудно-частотним спектром у полосі від $f_{1}$ до $f_{2}$.

Дані спектри для дискретного набору частот можуть бути отриманими за допомогою електродинамічних методів розрахунку, зокрема описаних у роботах $[1 ; 12-14]$, за допомогою солверів FEKO [23], HFSS [24] або іншими наявними методами.

Комплексні частотні спектри, що розглядаються, є швидкоосцилюючими функціями частоти. Тому для розрахунку інтегралу у формулі (3) використовується кусочно лінійна апроксимація частотного спектру $G_{n p}\left(f, \varepsilon_{n}, \beta_{n}\right) \equiv G_{n p}(\omega)$ між дискретними частотами $\omega_{m}=2 \pi f_{m}$ :

$$
G_{n p}(\omega)=a_{1 m} \omega+a_{2 m},\left[\omega_{m} \leq \omega \leq \omega_{m+1}\right],
$$

де $m=\overline{1, M-1}, M-$ кількість дискретних частот, на яких даний спектр визначено.

3 урахуванням (4) співвідношення (3) перепишемо у наступному вигляді:

$$
E=\sum_{m=1}^{M-1} \int_{\omega_{m}}^{\omega_{m+1}}\left|\left(a_{1 m} \omega+a_{2 m}\right)\right|^{2} d \omega
$$

У виразі (5) і далі залежність енергії прийнятого сигналу від $f_{0}, \Delta f, \varepsilon_{n}, \beta_{n}$, для спрощення запису опущено.

Інтеграл по відрізку $\left[\omega_{m}, \omega_{m+1}\right]$ може бути обчисленим аналітично. Остаточно вираз для енергії прийнятого сигналу буде мати вигляд:

$$
E=\sum_{m=1}^{M-1}\left|0,5 a_{1 m}\left(\omega_{m+1}^{2}-\omega_{m}^{2}\right)+a_{2 m}\left(\omega_{m+1}-\omega_{m}\right)\right|^{2} \text {. }
$$

Невідомі коефіцієнти $a_{1 m}, a_{2 m}$ у (6) можуть бути знайденими з використанням виразів для складових спектру на сусідніх частотах: 


$$
\begin{gathered}
a_{1 m}=\frac{G_{n p 1 m+1}-G_{n p 1 m}}{\omega_{m+1}-\omega_{m}} ; \\
a_{2 m}=\frac{G_{n p 1 m} \omega_{m+1}-G_{n p 1 m+1} \omega_{m}}{\omega_{m+1}-\omega_{m}} .
\end{gathered}
$$

Таким чином, використовуючи суму (6) і допоміжні вирази (7), (8), можна розрахувати енергію прийнятого сигналу по дискретному частотному спектру $G_{\text {пр }}\left(f, \varepsilon_{n}, \beta_{n}\right)$. Далі, застосовуючи вирази (1) i (2), за максимальними значеннями середніх енергій можна обрати середню, мінімальну і максимальну частоту спектру зондувального сигналу, якім відповідає максимальна інтенсивність сигналів, відбитих об'єктами $K$ заданих типів, у визначеному секторі кутомісних і азимутальних ракурсів.

\section{2. Метод математичного моделювання вторинного випромінювання снарядів, що застосовувався}

Вибір конкретного методу розрахунку характеристик вторинного випромінювання залежить від електричних розмірів, матеріалу і складності форми об'єкту [6; 8-12]. Як і у роботі [1], для математичного моделювання частотних спектрів сигналів, відбитих снарядами, застосовувався метод, заснований на розв'язанні інтегрального рівняння магнітного поля, детально описаний у монографії [12]. Даний метод був розроблений раніше для розрахунку характеристик вторинного випромінювання радіолокаційних об'єктів резонансних розмірів і раніше застосовувався для розрахунку електромагнітних відгуків крилатих ракет, наземної техніки у метровому діапазоні хвиль. Метод отримав подальший розвиток для моделювання відгуків об'єктів більш великих електричних розмірів і дозволяє проводити розрахунок електромагнітних полів, розсіяних об'єктами, розміри яких складають декілька довжин хвиль, що відповідає границі резонансної і високочастотної областей. Уточнено параметри алгоритму розрахунку для даного випадку, які дозволяють проводити моделювання характеристик вторинного випромінювання снарядів у L i S діапазонах частот із високою точністю. До таких параметрів відносяться:

- розмір елементарних ділянок поверхні снаряду, на яких щільність поверхневого електричного струму вважається постійною;

- кількість додаткових вузлів струму усередині об'єкту для усунення неоднозначних розв'язків інтегрального рівняння магнітного поля $[10 ; 12]$ та спосіб їх нанесення.

Геометричні розміри снаряду 9М22 ракетної системи залпового вогню (РСЗВ) "Град” та снарядів артилерії ОФ462 та ОФ25 наведено у табл. 1. Моделі їх поверхонь подано на рис. 1. У діапазоні частот $f=1-3$ ГГи (довжини хвиль $\lambda=30-10 \mathrm{~cm}$ ) діа- метр снарядів перевищує довжину хвилі, а їх довжина складає до 22,7入 (снаряд 9М22).

Вказані параметри алгоритму розрахунку встановлювались шляхом математичного моделювання. На різних частотах досліджуваного діапазону 1-3 ГГц проводились розрахунки для різних параметрів алгоритмів до отримання усталених значень ЕПР снаряду (різниця у значеннях ЕПР не перевищувала 1-3 \% для різних ракурсів снаряду).

Таблиця 1

Геометричні розміри снарядів, що досліджуються

\begin{tabular}{|l|c|c|}
\hline $\begin{array}{c}\text { Назва системи (назва } \\
\text { снаряду) }\end{array}$ & $\begin{array}{c}\text { Довжина, } \\
\text { м }\end{array}$ & $\begin{array}{c}\text { Діаметр } \\
\text { (калібр), м }\end{array}$ \\
\hline $\begin{array}{l}\text { РСЗВ БМ-21 “Град” } \\
\text { (снаряд 9М22) }\end{array}$ & 2,27 & 0,122 \\
\hline $\begin{array}{l}\text { Гаубиця Д-32 } \\
\text { (снаряд ОФ462) }\end{array}$ & 0,512 & 0,122 \\
\hline $\begin{array}{l}\text { Самохідна гаубиця 2С3 } \\
\text { “Акація” } \\
\text { (снаряд ОФ25) }\end{array}$ & 0,709 & 0,152 \\
\hline
\end{tabular}

Джерело: розроблено авторами.

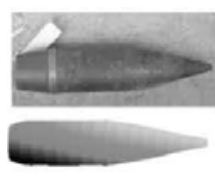

a
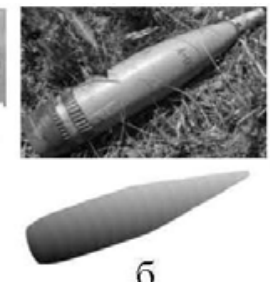

6

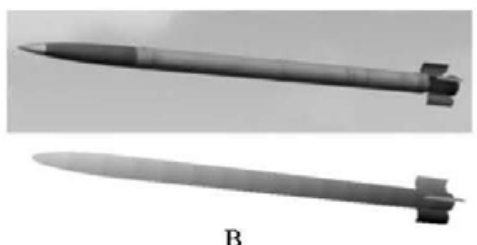

Рис. 1. Моделі поверхонь снарядів: а - ОФ462,

$$
\text { б- ОФ } 25, \text { в - 9M22 }
$$

Джерело: розроблено авторами.

Як і раніше вузли струму наносяться на поверхню снаряду із кроком, пропорційним радіусам кривизни локальних ділянок поверхні. На корпусах снарядів крок дискретизації не перевищує величини $0,1-0,14 \lambda$. У близькості країв крил снаряду 9М22

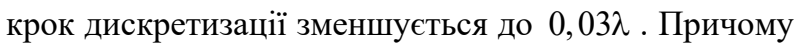
у околиці краю $0,01 \lambda$ вузли струму не наносяться. Кількість додаткових внутрішніх вузлів складає 1520 \% від кількості вузлів струму на поверхні.

У роботі [12] зазначено, що з урахуванням необхідності усунення неоднозначних розв'язків інтегрального рівняння магнітного поля, краща точність розрахунку ЕПР резонансного об'єкту забезпечується при нанесенні додаткових вузлів струму у середині об'єкту на поверхні, що являє собою аналітичне продовження основної поверхні об'єкту. При цьому відстань від додаткової внутрішньої поверхні 
до основної має складати величину $0,01 \lambda$. У якості аналітичного продовження поверхні снаряду зручно використовувати циліндричну поверхню. При проведенні розрахунків електромагнітних відгуків снарядів у полосі частот $1-3$ ГГи різниця радіусів основної і внутрішньої поверхонь має змінюватись у межах 1-3 см. Для уніфікації алгоритму розрахунку (використання єдиної сітки вузлів поверхневого струму і внутрішніх вузлів у всьому досліджуваному діапазоні частот) шляхом математичного моделювання встановлено, що для збереження точності 1-3 \% додаткові вузли мають наноситись на внутрішній циліндричній поверхні, радіус якої менший за радіус основної поверхні снаряду на величину $(0,2 \ldots 0,21) \lambda_{\min }$, де $\lambda_{\min }-$ мінімальна довжина хвилі $з$ досліджуваного діапазону. При цьому кількість додаткових внутрішніх вузлів має складати величину 15-20\% від кількості вузлів основної сітки.

Проведене удосконалення електродинамічного методу розрахунку характеристик вторинного випромінювання металевих об'єктів резонансних i достатньо великих електричних розмірів (діаметр снаряду більший за довжину хвилі, його довжина більша за $20 \lambda$ ) дозволяє проводити моделювання електромагнітних відгуків снарядів у достатньо широкій полосі частот та при достатньо великій кількості ракурсів снарядів відносно РЛС без суттєвих часових втрат, при збереженні високої точності обчислень. На основі описаного удосконаленого електродинамічного методу створено алгоритм розрахунку на основі сучасної мови програмування Fortran. Розроблений пакет програм 3 використанням комп'ютеру із 64-розрядною системою Windows 10 , процессором Intel Core I5 (3 ГГц) і 8 ГБ оперативної пам'яті забезпечує обчислення електромагнітних відгуків снаряду 9М22 (модель поверхні снаряду складають 3100 вузлів поверхневого струму, 465 внутрішніх додаткових вузлів) на 201 частоті, для 549 ракурсів і двох ортогональних поляризацій протягом 7-8 хв.

Описаний удосконалений алгоритм розрахунку застосовувався для моделювання частотних спектрів широкосмугових радіолокаційних сигналів, відбитих снарядами трьох зазначених вище типів при різних умовах опромінення.

\section{3. Результати розрахунку енергії відбитого сигналу від різних артилерійських снарядів}

У даному розділі обговорюються результати застосування запропонованого методу аналізу енергії відбитих сигналів для вибору раціонального діапазону частот зондувальних сигналів РЛС КББ при радіолокації снарядів трьох різних типів. Дослідження характеристик вторинного випромінювання снаряду 9M22 ракетної системи залпового вогню
(РСЗВ) “Град" та снарядів артилерії ОФ462 та ОФ25, проведені у роботах [1; 13-14], показують, що радіолокаційному зондуванню зазначених снарядів сигналами у діапазоні частот 1-3 ГГц (L, S діапазони) відповідає певний виграш у інтенсивності вторинного випромінювання. За допомогою розробленого методу проведено розрахунки енергій відбитих снарядами сигналів у зазначеному частотному діапазоні, для найбільш імовірних ракурсів.

Процес вибору полоси частот зондувального сигналу розпочинається 3 аналізу об'єктів локації, як вторинних випромінювачів. Характерні розміри снарядів, що досліджувались, наведено у табл. 1.

Снаряди є розсіювачами 3 металевою поверхнею, яку можна вважати ідеально провідною. Снаряд РСЗВ “Град” калібру 122 мм має суттєво більший повздовжній розмір ніж артилерійські снаряди ОФ462 і ОФ25 калібру 122 мм і 152 мм відповідно. Артилерійські снаряди за повздовжнім розміром відрізняються між собою не так суттєво. Калібр снарядів та їх повздовжній розмір відповідають резонансній області розсіювання (границі резонансної і високчастотної області у випадку 9М22) при зондуванні сигналами L, S діапазону.

Не зважаючи на порівняно просту форму, вторинне випромінювання снарядів у залежності від ракурсу має складний характер [1; 13-14]. Тому для 3'ясування раціональних параметрів зондувального сигналу важливо мати інформацію про характеристики вторинного випромінювання снарядів у діапазоні найбільш важливих азимутальних і кутомісних ракурсів. Такі ракурси можуть бути обраними з аналізу параметрів траєкторій снарядів - початкового кута вильоту снаряду, можливого взаємного розташування РЛС КББ та артилерійських позицій тощо. При цьому найбільш важливою є початкова ділянка траєкторії. Виходячи з аналізу застосування артилерійських систем та РСЗВ, при розрахунках кут місця опромінення снарядів змінювався у межах від 0 до 40 град. Враховуючи найбільш імовірні сектори вогню у горизонтальній площині, азимут змінювався у межах $0 \pm 60$ град. При цьому кут місця і азимут, що дорівнюють нулю, відповідали зондуванню у напрямку осі снаряду. Попередні результати досліджень діаграм зворотного вторинного випромінювання снарядів [1; 13-14] показали, що для детального врахування зміни ЕПР від ракурсів у кутомісній і азимутальній площинах крок зміни кута місця може складати 5 град., а кожному фіксованому значенню кута місця має відповідати азимутальний кут, який змінюється 3 меншим кроком 1 град.

Проведено розрахунки електромагнітних відгуків снарядів у діапазоні частот 1-3 ГГи із кроком 10 МГи.

На рис. 2 (a, б) показані результати розрахунку енергії відбитих снарядами сигналів для трьох зна- 
чень ширини спектру зондувального сигналу 50 МГu, 80 МГu та 100 МГu. Розширення ширини спектру зондувального сигналу РЛС КББ дозволить підвищити завадозахищеність радіолокатору та реалізувати алгоритм розпізнавання типу стріляючої позиції (артилерія / РСЗВ) [1]. Середня частота зондувального сигналу змінювалась також із кроком 10 МГц. Наведені результати відповідають моностатичній РЛС і вертикальній поляризації. Розрахунок енергії відбитих сигналів проводився для випадку, коли снаряди опромінювались сигналом 3 рівномірним амплітудно-частотним спектром 3 амплітудою напруженості магнітного поля $1 \mathrm{~A} / \mathrm{M}$.
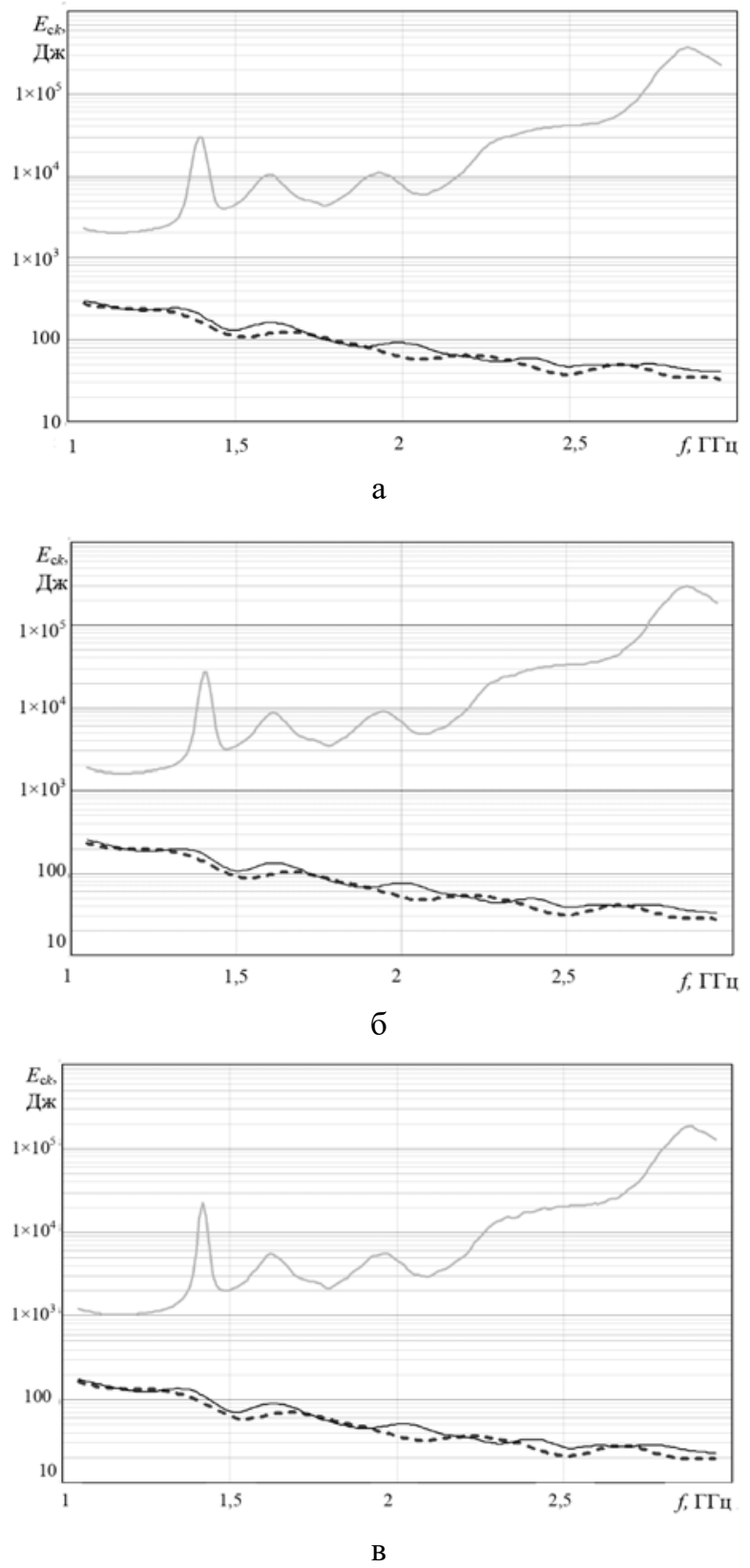

Рис. 2. Енергія відбитого сигналу від трьох типів снарядів з різної ширини спектру:

а - ширина спектру 100 МГц; б -80 МГц; в - 50 МГЦ

Джерело: розроблено авторами.
Сіра суцільна лінія відповідає енергії сигналу, відбитого снарядом 9М22, чорна штрихова - снарядом ОФ462, а чорна суцільна - ОФ25.

Як видно з рис. 2, при однакових умовах опромінення енергія сигналу, відбитого снарядом 9М22, на декілька порядків вище енергії сигналів від снарядів ОФ25 та ОФ462 у всьому діапазоні частот, що розглядається. Даний факт пояснюється його геометричними розмірами та наявністю двох відгуків від передньої і задньої частини снаряду на імпульсних широкосмугових відгуках, які досліджувались у роботі [1]. Характер зміни енергії відбитого сигналу в залежності від частоти зондувального сигналу від снаряду 9м22 та снарядів ОФ25 та ОФ462 має відмінності. Для снаряду 9М22 енергія відбитого сигналу зі збільшенням центральної частоти зондувального сигналу зростає, а для снарядів ОФ25 та ОФ462 навпаки зменшується. Отримані енергетичні частотні характеристики артилерійських снарядів калібру 152 мм і 122 мм є достатньо близькими. На практиці найбільш складними для радіолокації $€$ артилерійські снаряди. Тому перевагу при виборі полоси частот зондувального сигналу з урахуванням отриманих даних розрахунку енергії відбитих сигналів можна надати артилерійським системам, що використовують снаряди калібру 152 мм і 122 мм (ОФ25 та ОФ462 відповідно). Максимум інтенсивності сигналів, відбитих снарядами ОФ25 та ОФ462 спостерігається у полосі 1-1,4 ГГи. Даний факт можна пояснити резонансними властивостями снарядів у даній частотній області.

Слід зазначити, що максимальні значення i майже співпадіння значень енергії відбитого сигналу для цих снарядів відповідає полосі частот від 1 до 1,5 ГГц. Зі збільшенням електричних розмірів цих двох снарядів характер зміни енергії відбитих ними сигналів від частоти починає змінюватись і з'являються більші відмінності. Виділення спільного максимуму енергії для двох снарядів стає більш складним.

У реальних умовах позиції РСЗВ розташовуються на більшій відстані від лінії зіткнення, ніж артилерійські системи. Тому різниця у амплітудах відгуків снарядів артилерії і РСЗВ буде не такою значною.

Для більш детального з'ясування полоси частот зондувального сигналу 3 урахуванням частотних характеристик 3-х розглянутих снарядів можна використовувати інформацію про очікувані дальності стріляючих позицій. У цілому 3 наведених даних можна виділити наступні полоси частот, у яких можна очікувати максимальний рівень інтенсивності сигналів, відбитих розглянутими снарядами: 1-1,4 (забезпечується максимальний рівень інтенсивності сигналів відбитих артилерійськими снарядами калібру 152 мм і 122 мм, як найбільш складних для ра- 
діолокаціїі об'єктів); середні частоти близькі до локальних максимумів 1,4 ГГи і 1,6 ГГи (забезпечується максимум інтенсивності відбиття всіх трьох типів снарядів); полоса частот 2,7-3 ГГи (забезпечується максимальна дальність виявлення і точність вимірювання координат снаряду 9М22 РСЗВ “Град”).

Наведені дані свідчать про те, що зміна ширини спектру зондувального сигналу від $50 \mathrm{M \Gamma u}$ до 100 МГи суттєво на форму частотних характеристик розглянутих снарядів суттєво не впливає.

При наявності результатів розпізнавання типу стріляючої системи у РЛС КББ може бути реалізованим адаптивний вибір полоси частот, у якій забезпечується максимум енергії прийнятого сигналу.

\section{Висновки}

У роботі запропоновано метод визначення раціональної полоси частот зондувального сигналу для забезпечення максимальної інтенсивності сигналів, відбитих об'єктами декількох заданих типів. Метод базується на застосуванні математичного моделювання радіолокаційних відгуків шуканих об'єктів, детальному аналізі їх характеристик вторинного випромінювання. У якості критерію для вибору полоси частот використовується усереднена за імовірними ракурсами (у азимутальній і кутомісній площинах) енергія відбитого сигналу, як функція середньої частоти і ширини спектру.

Метод визначення раціональної полоси частот потребує проведення аналізу об'єктів локації, як розсіювачів електромагнітних хвиль, визначення найбільш імовірних ракурсів і дальностей радіолокаційного спостереження об'єктів.

Описаний метод застосовано для визначення інтервалів частот у межах L, S діапазону, у яких забезпечується максимум енергії сигналів, відбитих артилерійськими снарядами різних калібрів і снаряду РСЗВ “Град”. Для моделювання їх характеристик вторинного випромінювання при різних умовах локації застосовано удосконалений електродинамічний метод, що базується на розв'язанні інтегрального рівняння магнітного поля. Наведені дані розрахунку дозволили визначити ряд інтервалів частот, у яких забезпечується максимум енергії відбитих зазначеними снарядами сигналів. Запропонований метод може застосовуватись на етапі розробки перспективних РЛС КББ. Він також може бути поширеним на випадок радіолокаційних об'єктів інших класів.

\section{Список літератури}

1. Estimation of Radar Scattering Characteristics of Artillery Shells in Meter, Decimeter and Centimeter Wavelength Ranges / G. Zalevsky, O. Sukharevsky, V. Vasilets, M. Surgai // Radioelectronics and Communications Systems. - 2019. № 7(62). - P. 356-367. https//doi.org/10.3103/S0735272719070033.

2. Gjessing D.T. Target Adaptive Matched Illumination Radar Principles and Applications / D.T. Gjessing. - London: Peter Pelegrinus, 1986. $-172 \mathrm{p}$.

3. Gjessing D. Bistatic Matched Illumination Radar Involving Synthetic Aperture and Synthetic Pulse for Signal to Clutter Enhancement and Target Characterization / D. Gjessing, J. Saebboe // 2001 CIE International Conference on Radar. - Beijing, 15-18 October 2001. - P. 20-24.

4. Chen W.Ch. Robust Target Identification Using a Modified Generalized Likelihood Ratio Test / W.Ch. Chen // IEEE Transactions on Antennas and Propagation. - 2014. - № 1(62). - P. 264-273.

5. Искажения модулирующих функций многочастотных сигналов и их влияние на характеристики радиолокационных станций / И.Г. Леонов, А.В. Кондратенко, Д.В. Максюта, Ю.М. Рябуха // Системи обробки інформації. - 2002. № 4(20). - C. 180-184.

6. Knott E.F. Radar Cross Section / E.F. Knott, J.F. Shaeffer, M.T. Tuley. - London: Artech House, 1993. - 611 p.

7. Shirman Ya.D. Computer Simulation of Aerial Target Radar Scattering Recognition, Detection and Tracking / Ya.D. Shirman. - Norwood: Artech House, 2002. - 382 p.

8. Ширман Я.Д. Радиоэлектронные системы: Основы построения и теория. Справочник / Я.Д. Ширман. - М.: Радиотехника, 2007. - 512 с.

9. Skolnik M.I. Radar Handbook / M.I. Skolnik. - New York: McGraw-Hill, 2008. - 1348 p.

10. Gibson W.C. The Method of Moments in Electromagnetics / W.C. Gibson. - BocaRaton, London, NewYork: Chapman\&Hall, 2008. 288 p.

11. Electromagnetic Wave Scattering by Aerial and Ground Radar Objects / S. Nechitaylo, V. Orlenko, O. Sukharevsky, V. Vasilets. - Boca Raton: SRC Press Taylor \& Francis Group, 2014. - 334 p.

12. Sukharevsky O. Modeling of Ultrawideband (UWB) Impulse Scattering by Aerial and Subsurface Resonant Objects Based on Integral Equation Solving / O. Sukharevsky, G. Zalevsky, V. Vasilets // Advanced Ultrawideband Radar: Signals, Targets, and Applications. - 2016. - № 5. - P. 195-235. https://doi.org/10.1201/9781315374130.

13. Оцінювання рівня радіолокаційної помітності снаряду ракетної системи залпового вогню “Град” у різних діапазонах довжин хвиль / М.В. Сургай, Г.С. Залевський, В.О. Василець, О.І. Сухаревський // Збірник наукових праць Харківського національного університету Повітряних Сил. - 2017. - № 2(51). - С. 142-148.

14. Сургай М.В. Математичне моделювання характеристик вторинного випромінювання снаряду ОФ- 25 самохідної гаубиці 2С3 “Акація” у різних діапазонах довжин хвиль / М.В. Сургай // Наука і техніка Повітряних Сил Збройних Сил України. - 2018. - № 3(32). - С. 135-141. https://doi.org/10.30748/nitps.2018.32.18. 
15. Сухаревський О.І. Довідник характеристик розсіювання повітряних та наземних радіолокаційних об'єктів / О.І. Сухаревський, В.О. Василець, С.В. Нечитайло. - Х.: ХНУПС, 2019. - 304 с.

16. Барабаш Ю.Л. Математична модель та результати моделювання сигнального розпізнавання й визначення координат гармат в РЛС розвідки вогневих позицій / Ю.Л. Барабаш, Г.Д. Братченко, А.А. Гончарук // Вісник Київського Національного університету імені Тараса Шевченка. - 2005. - № 10. - С. 6-10.

17. Beenamole K.S. RCS Analysis of Mortar and Artillery Shells / K.S. Beenamole // VIII Annual International Conference ATMS-2015. - Bangalore, 2015. - Available at: http://atmsindia.org/tech_papers/2015/ 10RCS\%20ANALYSIS\%20OF\%20MORTAR\%20AND\%ARTILLERY\%20SHELLS.pdf.

18. Kenyon C. Numerical Computation of the Radar Cross Section of Rockets and Artillery Rounds / C. Kenyon, T. Dogaru. - USA: Army Research Laboratory, 2015. - 32 p. - Available at: https://apps.dtic.mil/dtic/tr/fulltext/ u2/a622300.pdf.

19. Kenyon C. Numerical Computation of the Radar Cross Section of a 120-mm Mortar / C. Kenyon, T. Dogaru. - USA: Army Research Laboratory, 2015. - 22 p. - Available at: https://ru.scribd.com/document/388325438/ARL-TN-0716-pdf.

20. Kenyon C. Numeric Computation of the Radar Cross Section of In-flight Projectiles / C. Kenyon, T. Dogaru. - USA: Army Research Laboratory, 2016. - 56 p. - Available at: https://apps.dtic.mil/sti/pdfs/AD1026240.pdf.

21. Barret T.W. Ultrawideband (UWB) Time-Frequency Signal Processing / T.W. Barret. - Boca Raton, London, New York: CRC Press Taylor \& Francis Group, 2016. - 494 p. https://doi.org/10.1201/9781315374130.

22. Kenyon C. Study of the Bistatic Radar Cross Section of a 155-mm Artillery Round / C. Kenyon, T. Dogaru. - USA: Army Research Laboratory, 2015. - 28 p. - Available at: https://apps.dtic.mil/sti/pdfs/AD1035373.pdf.

23. The official site FEKO.INFO. FEKO Comprehensive Electromagnetic Solutions. The Complete Antenna Design and Placement Solution. - Available at: http://www.feko.info.

24. The official site ANSYS.COM. ANSYS HFSS. - Available at: http://www.ansys.com/Products/ Simulation+Technology/Electronics/Signal+Integrity/ANSYS+HFSS

Надійшла до редколегї 01.02.2021

Схвалена до друку 16.03.2021

\section{Відомості про авторів:}

\section{Сургай Максим Володимирович}

старший викладач

Харківського національного університету

Повітряних Сил ім. І. Кожедуба,

Харків, Україна

https://orcid.org/0000-0002-3979-005X

\section{Залевський Геннадій Станіславович}

доктор технічних наук старший науковий співробітник професор Харківського національного університету

Повітряних Сил ім. І. Кожедуба,

Харків, Україна

https://orcid.org/0000-0002-6173-0571

\section{Горслишев Станіслав Анатолійович}

кандидат технічних наук доцент

старший науковий співробітник

Національної академії Національної гвардії України,

Харків, Україна

https://orcid.org/0000-0003-1689-0901

\section{Угринович Олег Ігорович}

кандидат військових наук доцент

професор Національного університету оборони

України ім. І. Черняховського,

Київ, Україна

https://orcid.org/0000-0001-6644-7620

\section{Джус Володимир Всеволодович}

кандидат технічних наук доцент

Харківського національного університету

Повітряних Сил ім. І. Кожедуба,

Харків, Україна

https://orcid.org/0000-0003-1762-1543

\section{Information about the authors:}

Maksim Surgai

Senior Instructor

of Ivan Kozhedub Kharkiv National

Air Force University,

Kharkiv, Ukraine

https://orcid.org/0000-0002-3979-005X

\section{Gennady Zalevsky}

Doctor of Technical Sciences Senior Research Professor of Ivan Kozhedub Kharkiv National

Air Force University,

Kharkiv, Ukraine

https://orcid.org/0000-0002-6173-0571

\section{Stanislav Horielyshev}

Candidate of Technical Sciences Associate Professor

Senior Research of National Academy

of National Guard of Ukraine,

Kharkiv, Ukraine

https://orcid.org/0000-0003-1689-0901

\section{Oleh Uhrynovych}

Candidate of Military Sciences Associate Professor Professor of National Defence University of Ukraine named after Ivan Cherniakhovskyi, Kyiv, Ukraine https://orcid.org/0000-0001-6644-7620

\section{Volodymyr Dzhus}

Candidate of Technical Sciences Senior Lecturer of Ivan Kozhedub Kharkiv National

Air Force University,

Kharkiv, Ukraine

https://orcid.org/0000-0003-1762-1543 
ВЫБОР ПОЛОСЫ ЧАСТОТ ЗОНДИРУЮЩЕГО СИГНАЛА СООТВЕТСТВУЮЩЕГО МАКСИМАЛЬНОМУ УРОВНЮ ВТОРИЧНОГО ИЗЛУЧЕНИЯ РАЗНЫХ ОБЪЕКТОВ

М.В. Сургай, Г.В. Залевский, С.А. Горелишев, О.И. Угринович, В.В. Джус

Рассматриваются вопросы согласования полосы частот зондирующего сигнала с различными воздушными объектами. Предлагается метод выбора рациональной частоты зондирующего сигнала для обеспечения максимального уровня вторичного излучения воздушных объектов заданного типа. Метод основан на использовании электродинамических математических моделей вторичного излучения радиолокационных объектов и оценки усредненного по возможным ракурсам энергии отраженного сигнала как функции средней частоты и ширины спектра зондирующего сигнала. Приводится и анализируется результаты расчета энергии отраженных сигналов для трёх разных типов снарядов артиллерии в L и S диапазонах частот. Даны предложения для выбора полосы частот для зондирования разных типов снарядов.

Ключевые слова: энергия отраженного сигнала, математическое моделирование вторичного излучения, радиолокационная станиия контрбатарейной борьбы, радиолокационный объект, полоса частот.

\section{SELECTION OF PROBING SIGNAL FREQUENCY BAND, CORRESPONDED TO MAXIMUM LEVEL OF SECONDARY RADIATION OF VARIOUS OBJECTS}

M. Surgai, G. Zalevsky, S. Horielyshev, O. Uhrynovych, V. Dzhus

The issues of matching the frequency band of the probing signal with various aerial objects are considered in the work. A method is proposed for selecting a rational frequency band of the probing signal to provide the maximum level of secondary radiation from aerial objects of specified types. As a criterion for choosing such a frequency band, we use the energy of the signals reflected by the investigated objects, averaged over the probable aspects of the scatterers relative to the radar in the azimuthal and elevation planes. Mentioned energy is considered as a function of the central frequency and bandwidth of the probing signal spectrum. Considered method for determining the rational frequency band provides for the analysis of radar objects, as scatterers of electromagnetic waves, the determination of the most probable aspect angles and ranges of objects radar surveillance. Method is based on the using an electrodynamic mathematical models of the radar objects secondary radiation. Results of calculating the energies of reflected signals for three different types of artillery shells in the L and S frequency bands are presented and analyzed. We briefly discuss the developed method based on solving magnetic field integral equation for electric current density at the perfectly conducting object surface, which was used for numerical analysis artillery shells electromagnetic responses for various radar sounding conditions. Proposals are given on the selection of the frequency bands for radar observation of various type artillery shells. The developed software allows to simulate the electromagnetic responses of artillery shells (the object diameter can exceed the wavelength, and its length can reach 20 wavelengths) in a sufficiently wide frequency band and with a significant number of objects aspect angles relative to the radar, while providing acceptable calculation time, and high accuracy of calculations. The proposed method can be applied at the stage of development of advanced counter battery radars to determine the rational operating frequency intervals. It can also be extended for the case of radar objects of other classes.

Keywords: counter battery radar, energy of reflected signal, frequency band, mathematical simulation of secondary radiation, radar object. 